\title{
Big Five Personality As Moderating The Effect Of Islamic Financial Planning
}

\author{
Dea Aryandhana Mulyana Haris ${ }^{1}$, Bayu Taufiq Possumah ${ }^{2}$, Dede Abdul Fatah ${ }^{3}$ \\ Master of Islamic Economic, Institut Agama Islam Tazkia, Indonesia \\ * Corresponding Author: \\ Email: dea.aryandhana@hotmail.com
}

\begin{abstract}
.
Islamic financial planning is a making process of financial planning in prudence to make it compatible with Islamic law in order to achieve the level of Al-Falah, that is the blessing of dunya and the salvation of akhira. Yet, with the importance of Islamic financial planning, the individuals who apply the Islamic financial planning in managing their wealth are still rare. So that this research intends to discover the influence of Islamic financial literacy towards each individual's Islamic financial planning, and moderation effects given by the big five personality trait. The researcher used the simple regression test to find out the Islamic financial literacy effects towards the Islamic financial planning, and used the analysis of moderated multiple regression (MMR) to take the idea that the big five personality trait can moderate the Islamic financial literacy effects towards the Islamic financial planning. The data is collected by using the survey technique through questionnaire distribution to 115 moslem entrepreneurs in Bandung area. The result of this research shows that the Islamic financial literacy influences the Islamic financial planning significantly, and the big five personality trait partially moderates that influence. Furthermore, the conscientiousness and opennes to experience personality trait moderate the influence of Islamic financial literacy towards Islamic financial planning, while the other three of big five personality trait do not moderate.
\end{abstract}

Keyword: Islamic financial planning, Islamic financial literacy, big five personality traits

\section{INTRODUCTION}

Wealth is a deposit from Allah Subhānahū wa taālā. We are not allowed to be arbitrary in using it. One of the knowledges that study about the planning of wealth use is the Islamic financial planning. The importance of financial planning for each idividual requires one to do the planning upon the owned financial. However, according to the Deputy of Comissioner for Consumer Education and Protection, the Indonesian society who have done the financial planning is only 12,90\% (Primadhyta, 2017). If the planning in financial matter is not done, it will affect each individual's life. As it is presented by the president of AXA Mandiri, that $80 \%$ of Indonesian young executive are threatened with poverty in the pension time due to the consumtive life style and the disorganized investment (Eksekutif, 2016). Regarding that, it can be seen that the 
effect of disorganized financial planning threatens one's life economically in the future.

Islamic financial planning focuses on one's obligation to manage or use the wealth that Allah Subhāanahū wa taālā has entrusted nicely and according to the guidance of Al-quran and Hadits. In essence, when following the mainstream of Islamic Economic Mazhab, which is the Islamic economic mazhab that adopts the neoclassical economic (modern) yet eliminates the riba variable and encloses the zakat and intention variable, it means that the factor which affects the Islamic financial planning is not much different from the factor that affects the conventional financial planning which has been extensively researched.

In several previous studies, financial literation is a factor that affects the financial planning. The research of Sobaya, et. Al (2016) examined about the effect of financial literation toward financial planning and the result from this research was that the knowledge variable (literation) significantly took effect toward the financial planning strategy. This research attempted to provide a new insight to the connection between financial literation and financial planning. This new insight used the variable of Islamic financial literation and Islamic financial planning, not the conventional financial literation and conventional financial planning like the previouse studies. The next new insight was by adding personality traits variable as the moderating variable. The personality traits was measured by using the The Big Five Personality (Robbins \& Judge, 2015), which was consisted of five dimensions namely openness to experience, conscientiousness, extraversion, agreeableness, and neuroticism. According to Sina (2014), there had been many financial researchers found out that the personality aspects influenced one's success in managing his financial and the used personality type in those studies relatively used the theory of big five personality. In line with this study, other studies examined the influence of big five personality traits toward financial planning, such as the study conducted by Nga \& Yien (2013) which gained that the dimension of big five personality traits such as conscientiousness, openness, agreeableness had a significant infuence toward financial decision-making. However, in other studies, big five personality traits was always made as an independent variable, whilst in this study big five personality traits was made as a moderating variable which moderated the effect of Islamic financial literation toward Islamic financial planning.

Islamic financial planning is highly required for the entrepreneurs. Moslem entrepreneurs not only have to aware about the knowledge of Islamic financial planning, but also have to apply it, whether by using the service of Islamic financial planner consultant or applying it after studying it on their own. Firdaus (2017) told that Islamic teaching seized that created organizations had to provide usefulness for many people. While Saktiawan (2009) told that from his experiences and studies in taking care of the empowerment of micro entrepreneurs matters through Baitul Maal wa Tanwil (BMT) since 1994, it was known that micro entrepreneurs who were able to increase their income yet deficient in managing their household finances, were not able 
to provide effects to their family welfare. High income that is accompanied by extravagant lifestyle will not gain profit but can cause being tangled up in a consumptive credit that is less useless. It can be said that the main purpose of business in Islam will not be achieved if the entrepreneurs do not making any financial planning.

According to the background outlined above, the identifications in this study are how the influence of Islamic financial literation toward Islamic financial planning on the moslem entrepreneurs in Bandung Area is, can the big five personality traits simultaneously moderate the influence of Islamic financial literation toward Islamic financial planning on the moslem entrepreneurs in Bandung Area and can the openness to experience, conscientiousness, extraversion, agreeableness, and neuroticism personality traits partially moderate the influence of Islamic financial literation toward Islamic financial planning on the moslem entrepreneurs in Bandung area.

The hypothesis of this study states that the Islamic financial literation significantly affects toward the application of Islamic financial planning, Big Five personality traits simultaneously moderates the influence of Islamic financial literation toward Islamic financial planning, and the personality traits of openness to experience, conscientiousness, extraversion, agreeableness, and neuroticism partially can moderate the influence of Islamic financial literation toward Islamic financial planning on the moslem entrepreneurs in Bandung Area.

The result of this study is expected to be able to provide a view, especially for the financial planner and, generally, for the moslem society, the factors that affect the application of Islamic financial planning, in order to take the right steps ahead in making the Islamic financial planning that is in accordance with the personality and the literation level.

\section{METHODS}

This research used quantitative approach with the explanatory method, moreover the used research design is causality. The research subject was moslem entrepreneurs in Bandung Area. The research was conducted from May 31st 2019 to July 2nd 2019. The sampling technique in this research used the probability sampling technique with the samples of 115 respondents, according to the sample size calculation proposed by Tabachnick \& Fidell (2013) is as follows:

$$
\begin{gathered}
\mathrm{N} \geq 104+\mathrm{m} \\
\mathrm{N} \geq 104+(11) \\
\mathrm{N} \geq 115
\end{gathered}
$$

The used data was the primary data with the survey method, which was the use of instrument in the form of questionnaire distributed to the respondents. The statement was made through the decline in theory of each variable to get the dimension which was subsequently made as a reference to make statements that could reflect each 
variable. After that, to find out the properness of each statement on the instrument, a validity and reliablity tests were conducted.

Before the hypothesis testing, data was tested through classical assumption test, which were normality and heteroscedasticity tests to find out whether the model was decent or not in the research. Next the data was analyzed by using two regression tests to gain a variable idea of Islamic financial planning that was affected by the variable of Islamic financial literation by using a simple linear regression test, whilst to gain an idea that big five personality trait could moderate the influence of Islamic financial literation on the Islamic financial planning, it used the moderated multiple regression analysis. Hartono (2013) stated that the test toward moderation variable could be done by looking at the increase of $\mathrm{R} 2$ determination coefficient (it can be seen at the Adjusted R2), the regression resemblance which contained the main effect and moderate effect from the regession resemblance which contained the main effect only. Nugroho (2012) told another method to test the moderation effect by using the moderated multiple regression (MMR) method, which was by using the $t$ test from the regression coefficient on the regression resemblance which contained the main and moderate effects, if the regression coefficient of variable XM was significant, it meant that there was a moderate effect from variable $M$ upon variable $X$ influence toward variable $\mathrm{Y}$. So that the used resemblance in this research is as follows:

$\mathrm{Y}=\mathrm{a}+\mathrm{b} \_1 \mathrm{X}+\varepsilon \ldots . .(\operatorname{model} 1)$

$\mathrm{Y}=\mathrm{a}+\mathrm{b} \_1 \mathrm{X}+\mathrm{b} \_2 \mathrm{M} \_1+\mathrm{b} \_3 \mathrm{M} \_2+\mathrm{b} \_4 \mathrm{M} \_3+\mathrm{b} \_5 \mathrm{M} \_4+\mathrm{b} \_6 \mathrm{M} \_5+\varepsilon \ldots \ldots .(\operatorname{model} 2)$

$\mathrm{Y}=\mathrm{a}+\mathrm{b} \_1 \quad \mathrm{X}+\mathrm{b} \_2 \mathrm{M} \_1+\mathrm{b} \_3 \mathrm{M} \_2+\mathrm{b} \_4 \mathrm{M} \_3+\mathrm{b} \_5 \mathrm{M} \_4+\mathrm{b} \_6 \mathrm{M} 55+\mathrm{b} \_7 \mathrm{XM}$ 1 $1+\mathrm{b} \_8$ XM_2+b_9 XM_3+b_10 XM_4+b_11 XM_5+ $\varepsilon$..... (model 3)

$\begin{array}{lll}\text { Where: } & = & \text { Islamic financial planning } \\ \mathrm{Y} & = & \text { constanta } \\ \mathrm{a} & = & \text { coefficient } \\ \text { b_(1-11) } & = & \text { Islamic financial literation } \\ \mathrm{X} & = & \text { extroversion } \\ \text { M_1 } & = & \text { agreeableness } \\ \text { M_2 } & = & \text { conscientiousness } \\ \text { M_3 } & = & \text { neuroticism } \\ \text { M_4 } & = & \text { openness to experience } \\ \text { M_5 } & & \text { Interaction variable } \\ \text { 『XM \_(1-5) } & = & \text { random error } \\ \varepsilon & = & \end{array}$

The resemblance regression on model 1 is the resemblance to know the influence of Islamic financial literation variable toward Islamic financial planning, while the regression resemblance on model 2 is used to know the influence of Islamic financial literation variable and five variables of big five personality traits toward Islamic financial planning, and model 3 is used to know the moderation effect of big five personality traits variable toward the influence of Islamic financial literation 
variable on Islamic financial planning variable. However, in this research model 2 is only used as the comparison when analyzing the regression of moderation variable with the testing of R2 value added method..

\section{RESULT AND DISCUSSION}

\section{Validity Test and Reliability Instruments}

The result of validity and reliability test on this research can be seen on Table 1. According to Table 1, it can be concluded that the whole statements in the questionnaire of this research are declared valid, it means that rcalculation $>$ rtable. Otherwise, each variable is declared to be able to provide the real value so that the measurement is trusted or it can be said as reliable due to the value of croanbach's alpha $>0.60$.

Table 1. Summary of Validity and Reliability Test Result

\begin{tabular}{|c|c|c|c|c|}
\hline No & Variabel & No. Item & $\begin{array}{l}\text { Coefisien } \\
\qquad \alpha\end{array}$ & $\begin{array}{l}\text { Non } \\
\text { Valid } \\
\text { Item }\end{array}$ \\
\hline 1 & Islamic Financial Planning & $1-17$ & 0,866 & - \\
\hline 2 & $\begin{array}{ll}\text { Islamic } & \text { Financial } \\
\text { Literation } & \\
\end{array}$ & $18-39$ & 0,896 & - \\
\hline 3 & Extroversion & $\begin{array}{c}40,45,50,55,60,65 \\
70,75\end{array}$ & 0,782 & - \\
\hline 4 & Agreeableness & $\begin{array}{c}41,46,51,56,61,66 \\
71,76,81\end{array}$ & 0,803 & - \\
\hline 5 & Conscientiousness & $\begin{array}{c}42,47,52,57,62,67, \\
72,77,82\end{array}$ & 0,839 & - \\
\hline 6 & Neuroticism & $\begin{array}{c}43,48,53,58,63,68 \\
73,78\end{array}$ & 0,724 & - \\
\hline 7 & Openness To Experience & $\begin{array}{c}44,49,54,59,64,69 \\
74,79,80,83\end{array}$ & 0,736 & - \\
\hline
\end{tabular}

\section{Classical Assumption Test}

Normality test in this research used two methods, which are Kolmogorov smirnov and probability plot methods.

Tabel 2. Recapitulation of Normality Test Using Kolmogorov-Smirnov Result

\begin{tabular}{ccc}
\hline Asymp. Sig & $\boldsymbol{\alpha}$ & Result \\
\hline 0,2 & 0,05 & Normal Distributed \\
\hline
\end{tabular}

Source: Research Result Data

According to the normality test result by using kolmogorov smirnov and probability plot, it can be seen that the value of asymp.sig is 0,2 , which is bigger than 0,5 and on 
Picture 1. The dots on the picture follows the direction of the diagonal line. The conclusion can be drawn that the model in this research can be normal distributed.

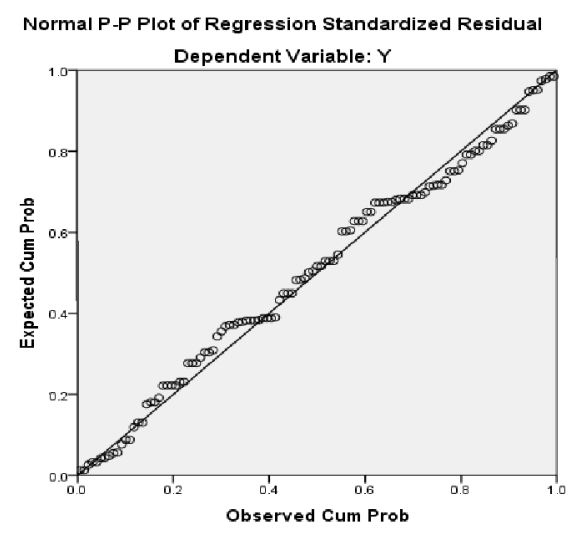

Picture 1. Normality Test Result Using Probability Plot

Next, heteroscedasticity test in this research can be seen through scatterplot. According to Picture 2. It can be seen that that dots are spread on the picture and do not make any pattern. So that it can be concluded that the model in this research is free from the heteroscedasticity.

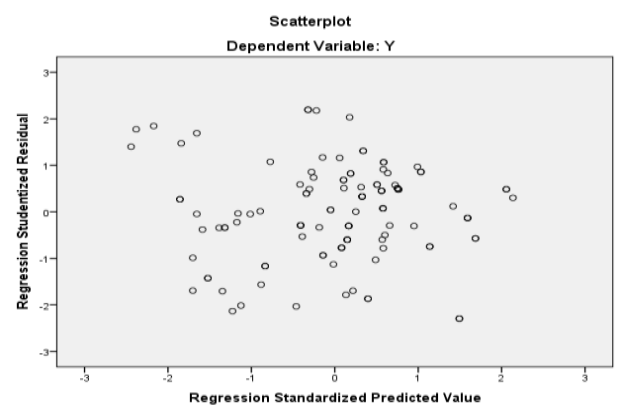

Picture 2. Heteroscedasticity Test result Using Scatterplot

\section{Hyphotesis Test}

Hyphotesis testing in this research used the simple linear regression test and moderated multiple regression (MMR) analysis. First of all, to test the moderation effect, it used moderated multiple regression (MMR), one of them was by using the comparison of $\mathrm{R} 2$ value addition or commonly called as $\mathrm{R} 2$ change. Therefore, it is required to do a determination coefficient test. Following is the summary of determination coefficient test result on this research by using model 2 and 3 .

Table 3. Hierarchical Multiple Regression Analysis

\begin{tabular}{ccccc}
\hline Model & $\mathrm{R}$ & R Square & $\begin{array}{c}\text { Adjusted R } \\
\text { Square }\end{array}$ & $\begin{array}{c}\text { R Square } \\
\text { Change }\end{array}$ \\
\hline 2 & .916 & .840 & .831 & .831 \\
\hline
\end{tabular}




\begin{tabular}{lllll}
\hline 3 & .926 & .858 & .842 & .018 \\
\hline
\end{tabular}

Source: Research Result Data

Next on this hypothesis testing part, it will be discussed about the testing partially with the $t$ test to know how big the influence of independent variable toward dependent variable and to know if there is any moderation effects from the moderation variable upon the influence of independent variable toward dependent variable.

Table 4. Regression Coefficient Table

\begin{tabular}{|c|c|c|c|c|c|c|c|}
\hline Model & & B & $\mathbf{S E}$ & $\beta$ & $t$ & $p$ & $\underset{\mathbf{n}}{\text { Kesimpula }}$ \\
\hline \multicolumn{8}{|l|}{ Model 1} \\
\hline Constant & & 7.739 & 3.136 & & 2.468 & $\begin{array}{r}.01 \\
5\end{array}$ & \\
\hline LKI & & .648 & .043 & .818 & $\begin{array}{r}15.10 \\
0 \\
\end{array}$ & $\begin{array}{r}.00 \\
0 \\
\end{array}$ & Diterima \\
\hline \multicolumn{8}{|l|}{ Model 3} \\
\hline Constant & & -3.834 & 9.570 & & -.401 & $\begin{array}{r}.69 \\
0\end{array}$ & \\
\hline LKI & & .528 & .136 & .665 & 3.882 & $\begin{array}{r}.00 \\
0\end{array}$ & \\
\hline Extroversion & & -.262 & .411 & -.133 & -.638 & $\begin{array}{r}.52 \\
5\end{array}$ & \\
\hline Agreeableness & & -.018 & .269 & -.010 & -.066 & $\begin{array}{r}.94 \\
7\end{array}$ & \\
\hline Conscientiousness & & 1.222 & .390 & .764 & 3.137 & $\begin{array}{r}.00 \\
2\end{array}$ & \\
\hline Neuroticism & & -1.881 & .931 & -.459 & 2.020 & $\begin{array}{r}.04 \\
6\end{array}$ & \\
\hline $\begin{array}{l}\text { Openness } \\
\text { Experience }\end{array}$ & To & 1.056 & .492 & .600 & 2.146 & $\begin{array}{r}.03 \\
4\end{array}$ & \\
\hline Interaksi 1 & & .007 & .005 & .405 & 1.301 & $\begin{array}{r}.19 \\
6\end{array}$ & Ditolak \\
\hline Interaksi 2 & & .008 & .004 & .501 & 1.961 & $\begin{array}{r}.05 \\
3\end{array}$ & Ditolak \\
\hline Interaksi 3 & & -.011 & .005 & -.759 & 2.098 & $\begin{array}{r}.03 \\
8\end{array}$ & Diterima \\
\hline Interaksi 4 & & .019 & .012 & .661 & 1.654 & $\begin{array}{r}.10 \\
1\end{array}$ & Ditolak \\
\hline Interaksi 5 & & -.017 & .007 & 1.206 & 2.547 & $\begin{array}{r}.01 \\
2 \\
\end{array}$ & Diterima \\
\hline
\end{tabular}

Source: Research Result Data 
According to the analysis result on table 4 . there is obtained a regression resemblance as follows:

\section{Model 1. $Y=7,739+0,648 X+\varepsilon$ \\ Model $3 \quad Y=-3,834+0,528 X-0,262 M_{1}-0,018 M_{2}+1,222 M_{8}-1,881 M_{4}+$$$
1,056 M_{5}+0,007 X M_{1}+0,008 X M_{2}-0,011 X M_{3}+0,019 X M_{4}-
$$$$
0,017 X M_{5}+\varepsilon
$$

\section{Hypothesis 1 Testing: Islamic Financial Literation Significantly Took Effect toward Islamic Financial Planning}

According to the analysis on Table 4. Showed that the obtained tcount was higher than ttable value that was $15,100>1,98900$ and the effect level of Islamic financial literation toward Islamic financial planning was $0,000<0.05$ which meant significant. That indicated that the Islamic financial literation significantly affected the Islamic financial planning in the positive direction where the obtained coefficient value was 0,648 which meant that when the Islamic financial literation had an enhancement as much as 1 unit of count then the Islamic financial planning experienced an enhancement as much as 0,648 unit of count with the assumption that the other variable was ceteris paribus. Therefore, the research of this result accepted H1 in the hypothesis because the result showed that the Islamic financial literation significantly affected the Islamic financial planning.

This went along with the previous study related to the financial literation (conventional) that significantly affected the financial planning (conventional) strategies that was done by Sobaya, et. Al (2016). It meant that the writer's opinion related to the factors that affected the Islamic financial planning was not much different from the factors that affected the conventional financial planning was acceptable, because this research result about the Islamic financial planning was in line with the previous research result about the conventional financial planning.

Theoretically, the definition of Islamic financial literation is individuals' ability to comprehend about financial that is grounded on Islamic teachings in order to be able to make, manage, and implement financial planning to achieve the welfare of dunya and akhira. It can be said that the main focus of financial literation is indeed to implement the financial planning itself. Even in the research done by Media Research Consultants Pte Ltd (2005), on of the used parameter to measure the level of financial literation is the financial planning.

This research result can be said that it is in accordance with the described sharia basis which is about how a moslem should have knowledge first before doing that. According to Surah Muhammad verse 19, "So know that there is no god but Allah, and ask forgiveness for your sins and for the believing men and the believing women. And Allah knows your return and the place of your abiding." It means that it would be better for a moslem to have a decent literacy about Islamic financial before 
implementing the Islamic financial planning, so that the planning done can be worth more and in accordance with Islamic sharia.

Based on the explanation above, it can be known that one's level of Islamic financial literacy can contribute in his Islamic financial planning attitude. It indicates that to upgrade the conscious behavior of moslem society generally about the Islamic financial planning, so as not to regret in the pension time, it can be done by focusing on fixing the Islamic financial literacy in the society by performing socialization about Islamic financial, either directly or through medias in society.

\section{Hypothesis 2 examination: Big Five Personality Traits Can Partially Moderate} The Influence of Islamic Financial Literacy toward Islamic Financial Planning

Based on the analysis result on Table 3., it showed that before interaction variable stepped into model, model was capable to clarify the variation that occurred on the Islamic financial planning was $84 \%$ and after the interaction variable stepped into the model, model's capability in clarifying the variation that occurred in the Islamic financial planning increased to $85,8 \%$. In other words, as the interaction variable stepped into the model, it could raise the value of R2 as much as 0,018 or $1,8 \%$ or increasing the Adjusted R2 from $83,1 \%$ to $84,2 \%$. So that model 3 was more effective in clarifying the Islamic financial planning phenomena if being compared to model 2. The value added of Adjusted R2 from the regression resemblance without interaction (model 2) to Adjusted R2 from the regression resemblance with interaction (model 3 ) as much as $1.8 \%$ showed that big five personality traits could partially moderate the influence of Islamic financial literacy toward Islamic financial planning. Therefore, this research result accepted $\mathrm{H} 1$ in the hypothesis because the result showed that big five personality traits could partially moderate the influence of Islamic financial literacy toward Islamic financial planning.

That matter was in line with the existed theories. The theory that was put forward by the Organisation for Economic Co-operation and Development (OECD) in Garg \& Singh (2018), explained that there were three dimensions on financial literacy, that are financial knowledge, financial attitude, and financial behavior. In line with that theory, Sina (2014) told that there were many financial researchers found that the personality aspect also affected one' success in managing his financial and the personality type used in those researches relatively was the big five personality traits. In sharia basis, Islamic psychology does not forbid the use of personality type used by the western psychology. In line with Hadist, Rasulullah Șallā Allāhu' alayh wa sallam decreed "You have better knowledge of the affairs of your world." (Sahih Muslim 2363).

\section{Hypothesis 3 Examination: Extrovertion Significantly Moderated The Influence of Islamic Financial Literacy toward Islamic Financial Planning}


According to the analysis result on Table 4, extroversion was homogolizer moderator variable. That was because the coefficient regression $b 2$ was not significant (where tcount that was obtained was lower than ttable value that was $-0,638<1,98304$ and $\mathrm{p}=0,525$ was more than 0,05 ). It meant that extroversion did not moderate the influence of Islamic financial literacy toward Islamic financial planning because the moderate variable (interaction between X and M1) had a level that was significantly higher than the determined significance level. So that this research denied H1 in the hypothesis because the research result showed that the extroversion personality trait did not significantly moderate the influence of Islamic financial literacy toward Islamic financial planning.

It meant that the extroversion dominant personality trait did not strengthen or weaken the influence of Islamic financial literacy toward Islamic financial planning. So that a moslem who had an extroversion dominant personality trait needed another supporting factor to will in applying the Islamic financial planning. It can be said that anybody with low financial literacy and had an extroversion dominant personality trait might not apply the Islamic financial planning, because the owned personality did not encourage to perform an Islamic financial planning. This research was in line with the result that was obtained by Nga \& Yien (2013), where an individual who had a high extroversion level did not have any significant influence toward financial decisionmaking.

Psychologically, extroversion is a personality dimension that describes somebody who is able to socialize, expressive, and confident (Robbins \& Judge, 2015). The most stand out trait in this personality is the high confidence, causing this personality trait has a weakness that is the tendency behavior to be careless because they do not think long before taking act or speaking (Savitra, 2017). That weakness becomes one factor because in Islamic financial planning requires an accuracy in designing the planning, whilst extroversion personality is inversely proportional to that.

\section{Hypothesis 4 Examination: Agreeableness Significantly Moderates The Influence of Islamic Financial Literacy toward Islamic Financial Planning}

Based on analysis result on Table 4, agreeableness belongs to homologizer moderator variable. That is because the regression coefficient b3 is not significant (where tcount that is obtained is lower than ttable value which is $-0,066<1,98304$ and $\mathrm{p}=0,947$ is more than 0,05 ) and the regression coefficient $\mathrm{b} 8$ is not significant (where tcount that is obtained is lower than ttable value which is $1,961<1,98304, \mathrm{p}=0,053$ is more than 0,05 ). It meant that agreeableness does not moderate the influence of Islamic financial literacy toward Islamic financial planning because moderate variable (interaction between $\mathrm{X}$ and M2) had a higher significance level than the determined significance level. So that this research result denied H1 in hypothesis because the 
research result showed that the agreeableness personality trait does not significantly moderate the influence of Islamic financial literacy toward Islamic financial planning.

It means that a moslem who has an agreeableness dominant personality trait requires any other supporting factors to will to apply the Islamic financial planning. It can be said that anybody with a low financial literacy and has an agreeableness dominant personality trait might not apply the Islamic financial planning, because the owned personality does not encourage to perform the Islamic financial planning. This research is not in line with the research that has been performed by Nga \& Yien (2013), where an individual who has a high level of agreeableness has a significant influence toward his financial decision-making.

Psychologically, agreeableness is a personality dimension which defines a person who is kind, cooperative, and trustworthy (Robbins \& Judge, 2015). The most stand out trait in this personality is understanding and kind-hearted to anyone, causing this personality has a weakness which is this individual often avoid conflict (Savitra, 2017). The individual who does not like any conflicts sometimes will be difficult to admit a conflicting opinions, that makes the information received becomes only one point of view and that point of view should be suitable with the previous opinion. That weakness becomes one factor why agreeableness personality trait does not moderate the influence of Islamic financial literacy toward Islamic financial planning, because in the Islamic financial planning there are still much debate related to the application, so that this matter will cause an avoided conflict, and this also causes a different research result from the previous result related to the conventional financial planning.

\section{Hypothesis 5 Examination: Conscientiousness Significantly Moderate The Influence of Islamic Financial Literacy toward Islamic Financial Planning}

According to the analysis result on Table 4, conscientiousness belongs to quasi moderator variable. That is because the b4 regression coefficient is significant (where the obtained tcount is higher than ttable value which is $-3,317>1,98304$ and $p=0,02$ is less than 0,05 ) and $\mathrm{b} 9$ regression coefficient is significant (where the obtained tcount is higher than ttable which is $-2,098>1,98304, p=0,038$ is less than 0,05 ). It meant that conscientiousness moderated the influence of Islamic financial literacy toward Islamic financial planning because the moderate variable (ineraction between $\mathrm{X}$ and M3) had a lower significance level than the obtained significance level. So that this research result accepted $\mathrm{H} 1$ in the hypothesis because the research result showed that conscientiousness personality trait significantly moderated the Islamic financial literacy toward Islamic financial planning.

Psychologically, conscientiousness, is a personality dimension which defines anybody who is responsible, reliable, persistent, and well-organized (Robbins \& Judge, 2015). The most stand out trait of this personality is they like to make a planning and 
do it well. Conscientiousness usually tends to be careful when doing something or do it with full of consideration (Savitra, 2017). In line with the basic trait, an individual who has a dominant conscientiousness personality trait will plan something carefully, including about the financial. So that it will be natural if the conscientiousness personality trait with the owned Islamic financial literacy will moderate the application of Islamic financial planning.

Hypothesis 6 Examinantion: Neuroticism Significantly Moderated The Influence of Islamic Financial Literacy toward Islamic Financial Planning

According to the analysis result on Table 4, neuroticism belongs to predictor moderator variable. That was because the b5 regression coefficient is significant (where the obtained tcount is higher than ttable value which is $-2.020>1,98304$ and $\mathrm{p}$ $=0,046$ is less than 0,05 ) and the $b 10$ regression coefficient is not significant (where the obtained tcount is lower than ttable value which is $-1,654<1,98304, p=0,101$ is more than 0,05 ). It meant that neuroticism did not moderate the influence of Islamic financial literacy toward Islamic financial planning because the moderate variable (interaction between $\mathrm{X}$ and M4) had a lower significance level than the obtained significance level. So that this research result did not accept H1 in the hypothesis because the research result showed that the neuroticism personality trait significantly moderated the influence of Islamic financial literacy toward Islamic financial planning.

It meant that a moslem who has a dominant neuroticism personality trait requires any other factors to will to apply the Islamic financial planning. It can be said that anyone with a low financial literacy and has a dominant neuroticism personality trait might not apply the Islamic financial planning, because the owned personality does not encourage to do the Islamic financial planning. This research is in line with the research that has been done by Brown \& Taylor (2011) and Nga \& Yien (2013), it has a result that neuroticism does not affect to the aspects of one's financial decisionmaking.

Psychologically, neuroticism or commonly called as emotional instability, is a personality dimension which defines a person who is jittery, depressed, and insecure (Robbins \& Judge, 2015). The most stand out trait of this personality is moody, causing this personality trait has a weakness that this individual often changes his mind (Savitra, 2017). That weakness becomes one factor why neuroticism personality trait does not moderate the influence of Islamic financial literacy toward Islamic financial planning, because in the financial planning, consistency is required in following up the planning that has been made. If the individual changes his mind often, then it will be difficult for him to plan his financial consistently. 


\section{Hypothesis 7 Examination: Openness to Experience Significantly Moderated the Influence of Islamic Financial Literacy toward Islamic Financial Planning}

According to the analysis result on Table 4, openness to experience belongs to quasi moderato variable. That was because the $\mathrm{b} 6$ regression coefficient is significant (where the obtained tcount was higher than ttable value which is $-2,146>1,98304$ and $\mathrm{p}=0,034$ is less than 0,05 ) and b1 1 regression coefficient is significant (where the obtained tcount is higher than ttable value which is $2,547>1,98304, p=0,012$ is less than 0,05$)$. It meant that openness to experience moderated the influence of Islamic financial literacy toward Islamic financial planning because the moderate variable (interaction between $\mathrm{X}$ and M5) had a lower significance level than the obtained significance level. So that this research result accepted H1 in the hypothesis because the result showed that openness to experience personality trait significantly moderated the influence of Islamic financial literacy toward Islamic financial planning.

It meant that a moslem who has dominant openness to experience personality trait will be easier to take interest in applying a well Islamic financial planning. It can be said that anyone with a low financial literacy and has dominant openness to experience personality trait will be likely to apply a well Islamic financial planning, because the owned personality encourages to do the Islamic financial planning. This research is in line with the research that has been done by Nga \& Yien (2013), where an individual who has a high level of openness to experience has a significant influence toward his financial decision-making, and also the research from Brown \& Taylor (2011), where the research that has been made has a result that the openness to experience personality trait provides a relatively big impact toward the amount of owned debt and financial.

Psychologically, openness to experience is a personality dimension which defines a person from his imaginative side, sensitivity, and curiosity (Robbins \& Judge, 2015). The most stand out trait of this personality is the curiosity about many different things, and it likes to introspect, play with the ideas (Ramdhani, 2012). That trait stimulates an individual to try out new things, it can be said that Islamic financial planning is a new thing that becomes something that is in demand for the individuals with dominant openness to experience personality trait.

\section{CONCLUSION}

Through analysis, it can be concluded that there is an influence between Islamic financial literacy and the application of Islamic financial planning and the big five partially can moderate the influence. Therefore, if it is seen from each personality trait, there are several traits that do not moderate. The conclusion that can be taken from this research is as follows. 
First, Islamic financial literacy takes place in the application of Islamic financial planning. Second, big five personality traits partially moderate the influence of Islamic financial literacy toward Islamic financial planning; third, extroversion, agreeableness, and neuroticism personality traits do not moderate the influence of Islamic financial literacy toward Islamic financial planning because those personality traits have a basic trait that is the opposite of Islamic financial planning; fourth, conscientiousness personality trait significantly moderates the influence of Islamic financial literacy toward Islamic financial planning. That is because moslem entrepreneurs with the dominance conscientiousness personality trait will plan something carefully, especially related to the finance that will affect their business cashflow; and five, the openness to experience personality trait significantly moderates the influence of Islamic financial literacy toward the application of Islamic financial planning. That is because moslem entrepreneurs with the dominance openness to experience personality trait want to try new things that may have any relation to their success of the business they run, so that the Islamic financial planning can be a new thing to try and be applied in their personal financial.

\section{ACKNOWLEDGMENTS}

For the sake of this research development, there are several suggestions for some parties that can be made as preferences as follows.

Firstly, for the government, to raise the application of Islamic financial planning in the society. The government should gain the society's Islamic financial literacy first. That can be done by cooperating with the Islamic Economics organization such as MES (Sharia Economic Society), IAEI (Association of Islamic Economics Experts), PPMI (Association of Indonesian Moslem Entrepreneurs) and there are still any other to hold a workshop or counseling regarding Islamic financial that is structured and continuous and also touch the lowest level of society.

Second, for moslem entrepreneurs, they have to explore the citemporer issues regarding Islamic Economics and raise Islamic financial literacy in order to make the business in line with the shariah guidance. Other than that, they have to start to make an Islamic financial planning consistently so that the wealth they have can be a halal, blessed, and abudant fortune.

Third, for the Islamic financial planners, they have to make a standard model of Islamic financial planning for later being delivered to the society through financial trainings or consultations regarding the way to make a financial planning that fits the Islamic guidance so that the owned wealth can be a halal, blessed, and abundant fortune. Moreover, this research indicated that Islamic financial literacy and big five personality trait questionnaire can be used to identify the beginning of clients' 
candidates of risk profile that is useful to determine the financial planning that fits the client.

Fourth, for the next researchers, due to the a few research regarding the Islamic financial planning, it is better for the next researchers to use other variables such as change the moderator variable into Islamic personality trait theory, or reliugisity. Moreover, other data analysis techniques such as structural equation modeling to maximize the research result.

\section{REFERENCES}

[1] Ali, M. M. (2016). Islamologi. Jakarta: Darul Kutubil Islamiyah.

[2] Brown, S., \& Taylor, K. (2011). Household Finances and the 'Big Five' Personality Traits. Discussion Paper No.6191.

[3] Eksekutif Terancam Miskin di Hari Tua. (2016, 26 Mei). Sektor Riil. 15 Oktober2017. https://economy.okezone.com/read/2016/05/26/320/1398346/80-eksekutif-terancam-miskin-dihari-tua

[4] Firdaus, A. (2017). Maslahah Performa (MaP) : Sistem Manajemen Kinerja Berbasis Maslahah. Yogyakarta : K-Media.

[5] Garg, N., \& Singh, S. (2018). Financial Literacy among Youth. International Journal og Social Economi, Vol. 45 (1), 173-186.

[6] Hartono. (2013). Metode Penelitian Bisnis. Yogyakarta: BPFE Ekonomi dan Bisnis UGM.

[7] Media Research Consultant Pte Ltd. (2005). Quantitative research on financial literacy levels in Singapore. report prepared for The MoneySENSE Financial Education Steering Committee (FESC). Singapore.

[8] Nga, J., \& Yien, L. (2013). The influence of personality trait and demographics on financial decision making among Generation Y. Young Consumers, Vol. 14 (3), 230243.

[9] Nugroho, A. W. (2012). Pengujian Efek Moderasi Melalui Analisis Regresi Berganda. Jurnal Pengukuran Psikologi dan Pendidikan Indonesia, Vol 1 (4), 229 -242.

[10] Primadhyta, Safyra. (2017, 21 Oktober). Hanya 12,6 Persen Masyarakat Indonesia Punya Perencanaan Keuangan. Berita Keuangan. 28 November2017. https://www.cnnindonesia.com/ekonomi/20171020194504-78-249871/hanya-126persen-masyarakat-indonesia-punya-rencana-keuangan

[11] Ramdhani, N. (2012). Adaptasi Bahasa dan Budaya Inventori Big Five. Jurnal Psikologi, 189-207.

[12] Robbins, S., \& Judge, T. (2015). Perilaku Organisasi (Ratna Saraswati \& Febriella Sirait, Penerjemah). Jakarta: Salemba Empat.

[13] Saktiawan, I. R. (2009). Islamic Financial Planning : Dialog Taktis Menyiasati Krisis. Bandung: Salamadani Pustaka Semesta.

[14] Savitra, Khanza. (2017, 28 April). Teori the Big Five Personality (Teori Sifat Kepribadian Model Lime Besar. Teori Psikologi. 22 Agustus 2019. https://dosenpsikologi.com/big-five-personality 
[15] Sina, P. G. (2014). Tipe Kepribadian Dalam Personal Finance . Jurnal JIBEKA Volume 8 (1), 54-59.

[16] Sobaya, S., et al, (2016). Pengaruh Literasi Keuangan Dan Lingkungan Sosial Terhadap Perencanaan Keuangan Pegawai Di Universitas Islam Indonesia Yogyakarta. MADANIA Vol 20, No.1, 115-128.

[16] Subiaktono. (2013). Pengaruh Personality Traits terhadap Perencanaan Keuangan Keluarga. Jurnal Dinaika Manajemen, Vol 4 (2), 150-163.

[17] Tabachnick, B. G., \& Fidell, L. S. (2013). Using Multivariate Statistics. Boston: Pearson Education. 